\title{
Chronic sinoatrial disorder (sick sinus syndrome): a possible result of cardiac ischaemia
}

\author{
DAVID B SHAW, NICHOLAS J LINKER, * PATRICIA A HEAVER, \\ ROGER EVANS $\uparrow$
}

From the Cardiac Department, Royal Devon and Exeter Hospital (Wonford), Exeter; ${ }^{\text {Department of }}$ Cardiological Sciences, St George's Hospital Medical School, London; and $\dagger$ Accident and Emergency Medicine, Cardiff Royal Infirmary, Cardiff

SUMMaRY Postmortem angiography was used to examine the blood vessels supplying the sinoatrial node in 25 subjects with chronic sinoatrial disorder (group 1). The results were compared with similar studies in $\mathbf{5 4}$ subjects who died of heart block and in whom sinus node function was normal (group 2). Although no significant lesion obstructing the blood flow to the sinus node was seen in the majority of those in group 1, there were abnormalities in seven cases, with reduced filling of the sinus node artery in five. In group 2 the sinus node artery filled normally in all cases despite major disease of the parent vessel in three. The combination of contralateral coronary artery disease with extensive atrial anastomoses was actively sought because this arrangement might predispose to a steal phenomenon. Such conditions were fully met in three cases in group 1 and two cases in group 2, and were found to a lesser extent in a further two cases in group 1 and three in group 2.

Although coronary artery disease was unlikely to be the principal cause of sinus node dysfunction in most of the cases studied it was relatively common and may have been a factor in about one third. Improved survival after myocardial infarction may increase the number of patients with chronic sinoatrial disorder of ischaemic origin.

Chronic sinoatrial disorder (sick sinus syndrome) is now one of the commonest conditions treated by pacemaker implantation, yet its aetiology remains in doubt. Acute dysfunction of the sinus node is commonly seen in the early stages of myocardial infarction but it usually disappears within the first $24-48$ hours $^{1}$ and initially coronary artery disease was assumed to be responsible for most cases of chronic dysfunction. ${ }^{2-4}$ More recently this has been disputed and the long term follow up of patients showing sinus node dysfunction in the acute phase of myocardial infarction has produced conflicting results. ${ }^{56}$ Currently necropsy studies have shown few major lesions of the blood vessels supplying the

Requests for reprints to Dr David B Shaw, Cardiac Department, Royal Devon and Exeter Hospital (Wonford), Barrack Road, Exeter EX2 5DW.

Accepted for publication 9 July 1987 sinus node, ${ }^{7-9}$ but the numbers of cases studied are small and even fewer have been investigated by postmortem angiography. Reviewing the subject Becker concluded that the aetiology remained in doubt and that a full angiographic study of the blood supply to the sinoatrial node was required to assess the role of coronary artery disease. ${ }^{10}$ As an additional factor he suggested that there might be a steal phenomenon through atrial collateral vessels, a possibility which had not been previously assessed. Another factor is the improved survival of patients with extensive cardiac infarction in which there may be major obstruction to the sinoatrial artery or its parent vessel.

We have investigated the blood supply to the sinus node by postmortem angiography in patients with chronic sinoatrial disorder. Patients dying of chronic heart block were used as controls because both they and the patients with sick sinus syndrome had been followed up in an identical manner in our department. 
Table 1 Basic data in the two groups (further details for group 1 are given in the appendix)

\begin{tabular}{|c|c|c|c|c|c|c|c|}
\hline \multirow[b]{2}{*}{ Group } & \multirow[b]{2}{*}{ No } & \multicolumn{2}{|c|}{$\operatorname{Age}(y r)$} & \multicolumn{2}{|c|}{ Follow up in months } & \multirow[b]{2}{*}{$\operatorname{Sex}(M / F)$} & \multirow[b]{2}{*}{ Paced } \\
\hline & & Mean & Range & Mean & Range & & \\
\hline $\begin{array}{l}1 \\
2\end{array}$ & $\begin{array}{l}25 \\
54\end{array}$ & $\begin{array}{l}75 \\
78\end{array}$ & $\begin{array}{l}56-92 \\
49-96\end{array}$ & $\begin{array}{l}55 \\
37\end{array}$ & $\begin{array}{l}1-186 \\
1-140\end{array}$ & $\begin{array}{l}20 / 5 \\
39 / 15\end{array}$ & $\begin{array}{l}19 \\
36\end{array}$ \\
\hline
\end{tabular}

\section{Patients and methods}

\section{PATIENTS}

Most of the material was obtained from patients who died while in the Devon Heart Block and Bradycardia Survey. ${ }^{11}$ All subjects were known to have suffered from either sinoatrial disorder or heart block for 28 days or more. For the purposes of analysis they were divided into the following groups:

Group 1 consisted of 25 subjects with chronic sinoatrial disorder. All were known to have had features of sinus node dysfunction for more than a month before death and 23 had been followed up in the Devon Survey. The angiographic findings in four cases were briefly described in $1977 .^{8}$
Group 2 consisted of 54 subjects with normal sinus node function but chronic second or third degree atrioventricular block and who had been followed up in the Devon Survey for one month or more.

Table 1 gives the age at the time of death, the follow up time, and the number of subjects paced in the two groups. The appendix gives further details of the patients in group 1 and table 2 gives electrocardiographic data. Sinus bradycardia was seen in 21 patients and bradycardia with junctional rhythm was present in another three patients. One case (No 207) did not have clinically significant bradycardia but did have episodes of sinoatrial block with sinus pauses lasting up to eight seconds. A further 18 patients had sinus pauses of $\geqslant 1.8 \mathrm{~s}$ on the standard

sle 2 Electrocardiographic findings in patients with sinoatrial disorder (group 1)

\begin{tabular}{|c|c|c|c|c|c|c|c|}
\hline $2 N o$ & $\begin{array}{l}\text { Sinus } \\
\text { bradycardia }\end{array}$ & Sinus` pause & $\begin{array}{l}\text { Junctional } \\
\text { rhythm }\end{array}$ & Tachycardia & $\begin{array}{l}\text { ECG } \\
\text { lowest rate }\end{array}$ & $A V$ conduction & $\begin{array}{l}S T / T \\
\text { wave abnormalities on entry }\end{array}$ \\
\hline & + & + & + & Atrial fibrillation & 34 & $\begin{array}{l}\text { RBBB, } 1^{\circ} \text { block, } \\
\text { intermittent CHB }\end{array}$ & \\
\hline & + & + & & & 45 & $\mathrm{CHB}$ & \\
\hline & + & + & + & & 31 & Normal & $\begin{array}{l}\text { ST depression I aVL, V5-6, } \\
\text { T inversion I, aVL }\end{array}$ \\
\hline & + & & & & 50 & $\begin{array}{l}\text { RBBB, } \\
\text { intermittent CHB }\end{array}$ & \\
\hline & + & + & + & & 33 & $\begin{array}{l}\text { Intermittent } 1^{\circ} \\
\text { block }\end{array}$ & $\mathrm{T}$ inversion I, III, aVL, V3-6 \\
\hline & + & & & $\begin{array}{l}\text { Atrial tachycardia and } \\
\text { fibrillation }\end{array}$ & 24 & LAHB, $1^{\circ}$ block & \\
\hline & + & + & & Atrial tachycardia & 30 & $1^{\circ}$ block & ST denrecsinn V4-6 \\
\hline & $\begin{array}{l}+ \\
+\end{array}$ & + & + & & $\begin{array}{l}37 \\
38\end{array}$ & $\begin{array}{l}\text { Normal } \\
\text { Normal }\end{array}$ & S1 depression v4-0 \\
\hline & + & + & & Atrial flutter & 25 & Normal & \\
\hline & + & + & & Atrial flutter & 50 & Normal & \\
\hline & $\begin{array}{l}+ \\
+\end{array}$ & + & + & $\begin{array}{l}\text { Atrial tibrillation } \\
\text { Atrial tachycardia }\end{array}$ & $\begin{array}{l}28 \\
39\end{array}$ & Normal & $\begin{array}{l}\text { ST depression I, V4-6 } \\
\text { T inversion I, II, aVL, V3-6 }\end{array}$ \\
\hline & + & & & Atrial flutter & 49 & Normal & \\
\hline & + & + & & Atrial fibrillation & 44 & Normal & T inversion II, III, aVF, \\
\hline \multirow[t]{9}{*}{.6} & + & + & + & Atrial flutter & 36 & Normal & \\
\hline & $\begin{array}{l}\top \\
+\end{array}$ & + & & & 39 & RBBB, $1^{\circ}$ block & \\
\hline & + & + & & & 46 & Normal & \\
\hline & + & + & + & $\begin{array}{l}\text { Atrial tachycardia; } \\
\text { ventricular tachycardia }\end{array}$ & 42 & Normal & \\
\hline & + & $\begin{array}{l}+ \\
+\end{array}$ & + & & $\begin{array}{l}34 \\
63\end{array}$ & $\begin{array}{l}\text { LAHB } \\
\text { Normal }\end{array}$ & ST depression V4-6 \\
\hline & & + & $\begin{array}{l}+ \\
+\end{array}$ & & 41 & Normal & \\
\hline & & + & + & Atrial tachycardia & 34 & Normal & \\
\hline & & + & + & Atrial fibrillation & 37 & $\begin{array}{l}\text { Intermittent } 1 \\
\text { block }\end{array}$ & \\
\hline & + & + & & & 46 & $\begin{array}{l}\text { RBBB, intermittent } \\
1^{\circ} \text { block }\end{array}$ & \\
\hline
\end{tabular}


electrocardiogram, or $\geqslant 2 \mathrm{~s}$ or more on ambulant electrocardiography. In three patients the relation of the duration of the pauses to the preceding PP intervals was compatible with sinoatrial block. Periods of junctional rhythm occurred in 12 patients and paroxysmal tachycardia was seen in 14 . There were major conduction disturbances in three patients and lesser abnormalities such as bundle branch block or first degree block in seven. No conduction abnormalities were seen in 15. By definition second or third degree block was present in all the subjects in group 2 and none had evidence of sinus node dysfunction.

During the period of the study postmortem angiography was carried out on four additional patients who had been seen during the acute stages of myocardial infarction with evidence of sinus node dysfunction. All had periods of sinus arrest and gross bradycardia which persisted up to the time of their death at $4,15,16$, and 17 days after the acute event.

\section{METHODS}

Most of the patients died at home and permission for necropsy was only obtained by the speedy cooperation of the patient's family doctor. Usually the family agreed to only a limited procedure; this was carried out as soon as possible after death. When the heart was removed particular care was taken to sever the superior vena cava 2 or $3 \mathrm{~cm}$ above its junction with the right atrium so that the sinoatrial node and its blood supply were not damaged. After initial inspection of the heart the coronary ostia were examined and then cannulated. Both coronary arteries were flushed with saline at low pressure to remove postmortem sludge and then the right coronary was perfused with a radio-opaque medium for $5 \mathrm{~min}$ at a pressure of $130 \mathrm{~mm} \mathrm{Hg}$. Radiographs of the heart were taken in three planes on a fine grain film (Mamoray RP3) with an Elema-Schonander skull unit with $40 \mathrm{kV}$ at $400 \mathrm{~mA}$, a focal spot of $0.6 \mathrm{~mm}$, and a focal film distance of 32 inches. Films were developed and if they were satisfactory, then the left coronary artery was perfused and a further set of $x$ rays was taken. The standard views were anterior-posterior, left lateral, and left anterior oblique; but in a proportion of patients additional views were taken. The injectate usually consisted of a barium suspension mixed with Colourpaque to which a little dissolved gelatine had been added. This mixture penetrated into vessels with diameters of between 25 and $30 \mu \mathrm{m}$.

After postmortem angiography of the heart in toto, we removed the block of tissue containing the junction between the superior vena cava and right atrium, pinned it out on a board, and $x$ rayed it to demonstrate the sinoatrial node artery and its branches. The heart was fixed for two or three weeks and blocks taken from the heart and main coronary arteries for histological examination. ${ }^{8}$ We used a $\overrightarrow{0}$ modification of the method described by Davies. ${ }^{12}$ 등 The angiograms were studied with an overhead $\bar{c}$ projector which gave a ninefold magnification. We $\widehat{\nabla}$ concentrated on the right coronary up to the origin of the posterior descending branch (where present) and the left coronary, including the initial parts of its $\vec{\circ}$ two main branches proximal to the first diagonal and $\overrightarrow{\vec{H}}$ second obtuse marginal. The widths of the arteries $\stackrel{\omega}{\omega}$ were measured and in narrowed areas the reduction in lumen was expressed as a percentage of the width of the preceding sections; obstructions of less than 0 $20 \%$ were classified as normal. We looked for vessels 0 running between branches of the sinoatrial node $\infty$ artery or its parent vessel and other atrial arteries, 웅 particularly those arising from the contralateral coronary artery. To be accepted as anastomotic ves- $\square$ sels they had to be seen on all three $x$ ray projections $\stackrel{\mathbb{0}}{\%}$ (fig 1). One or two connecting vessels were desig- $\frac{\mathbb{}}{3}$ nated as "some" and three or more as "many". If filling of atrial arteries stemming from the right coronary artery was poor after this vessel had been $\stackrel{\oplus}{\oplus}$ perfused, the appearances were reviewed after per-. fusion of the left coronary artery for evidence of an increased flow of contrast material via anastomoses. The potential for a steal phenomenon was identified only if there was an anastomosis between the sinus node artery proximal to the node and a branch of an $\stackrel{\perp}{\perp}$ obstructed $(50 \%$ or more) contralateral artery.

Filling of the sinoatrial node artery was assessed by examination of the initial angiograms of the whole heart and subsequent films of the tissue block containing the sinoatrial node. Filling was classified as "normal" where the vessel and its tributaries could be seen easily with sharp outlines on a standard $x$ ray viewing box and "reduced" if the vessel 3 was blurred with indistinct or barely visible tributaries. Filling was termed "poor" if the sinus node $\frac{\rho}{3}$ artery could only be discerned with difficulty using a bright light and "nil" if the artery was invisible on $x$ 공 rays of the whole heart or tissue block containing the $\frac{D}{O}$ sinus node.

The right coronary artery was identified as being ${ }_{\sigma}$ dominant if it gave rise to the posterior descending artery. ${ }^{13}$

\section{Results}

The left coronary artery was dominant in 10 of the 25 cases in group 1 and 15 of the 54 cases in group 2 . The origin of the sinus node artery was easily $\mathbb{\Phi}$ identified in all patients except case 187 in group $1, \stackrel{\overparen{\mathbb{D}}}{\mathbb{D}}$ in whom the left coronary artery was normal but did 

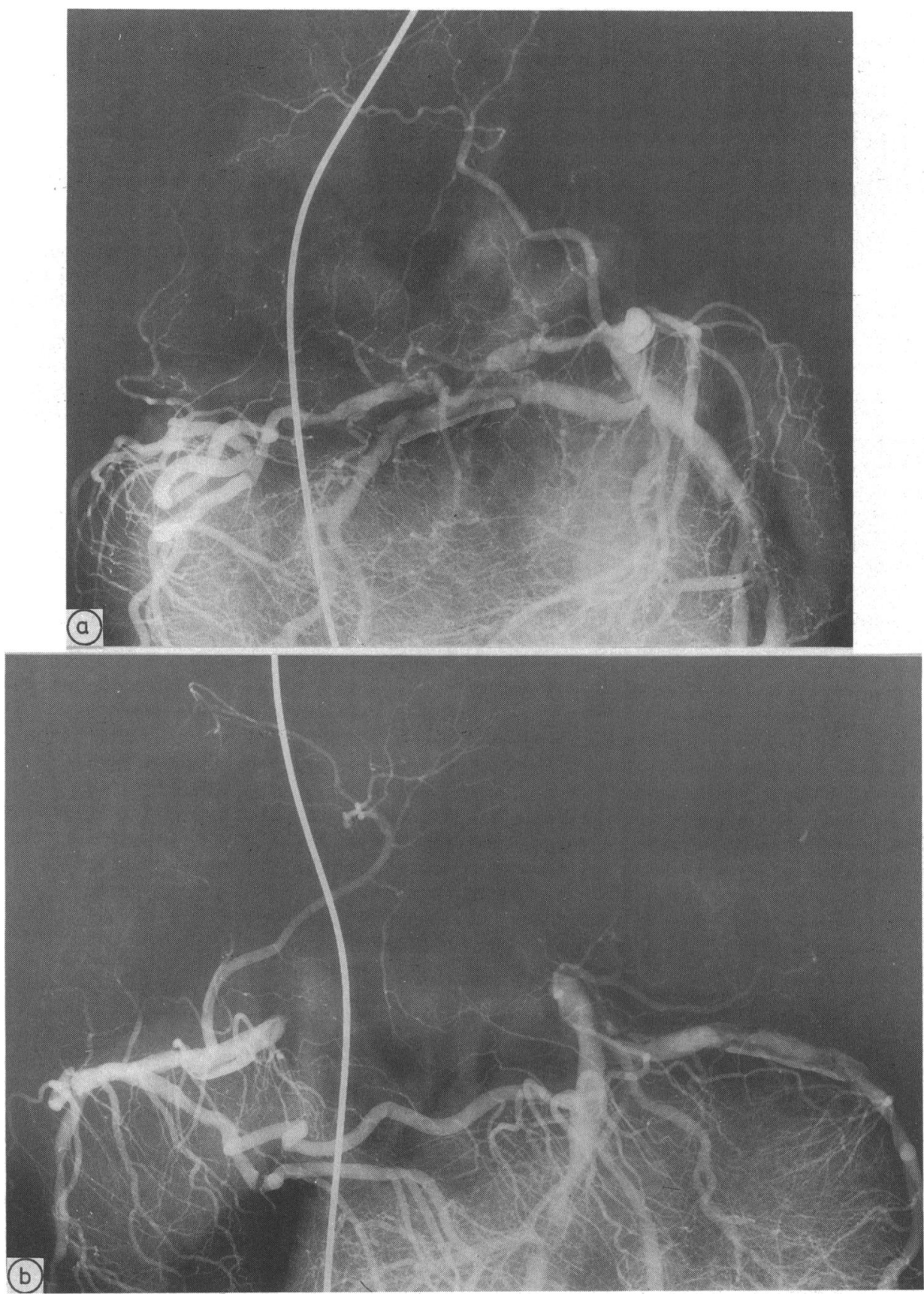

Fig 1 Angiograms of case 118 with both coronary arteries perfused and showing a large atrial artery arising from the right coronary artery which supplies the sinus node area. The oblique view (a) appears to show a series of anastomoses but the arterior-posterior view (b) shows separation of the vessels particularly in the upper atrium. 


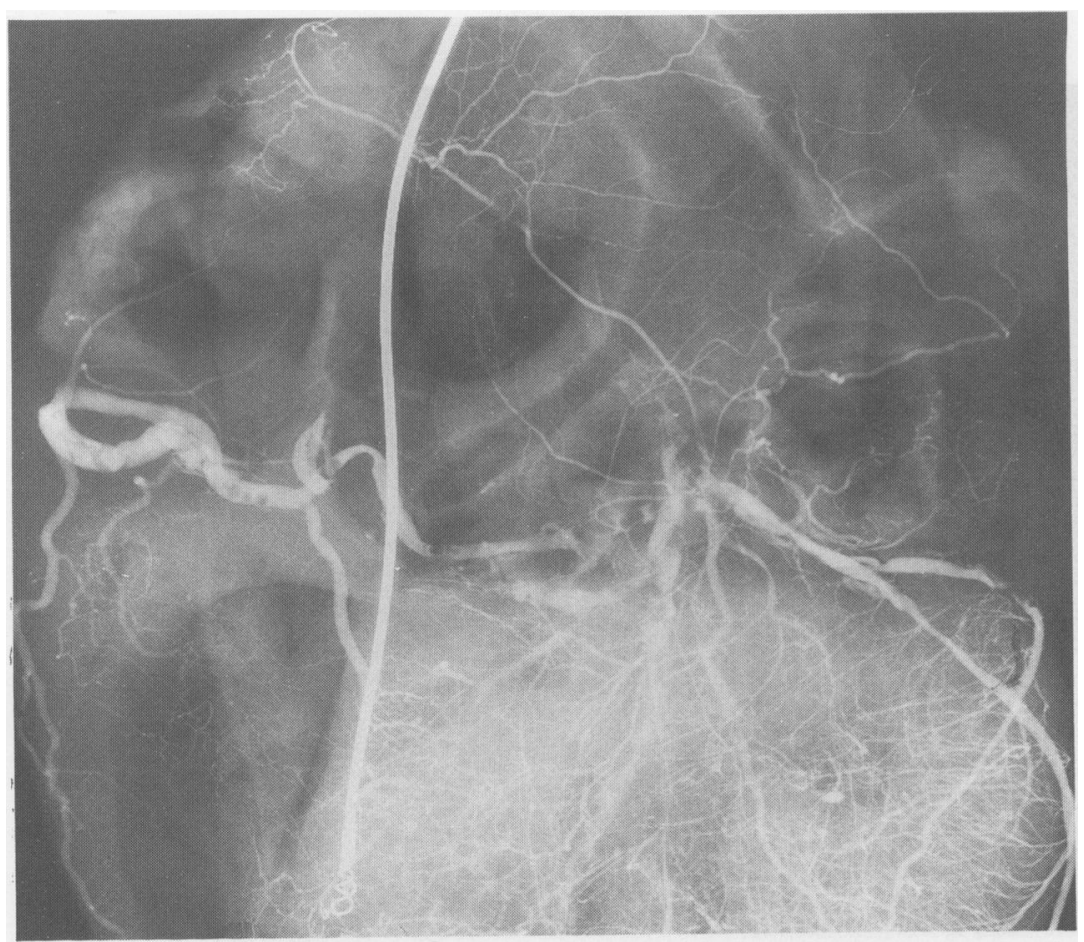

Fig 2 Anterior-posterior angiogram of case 243 after perfusion of both coronary arteries, showing gross general arterial disease but normal filling of the sinoatrial node artery which arises close to the origin of the left circumflex coronary artery.

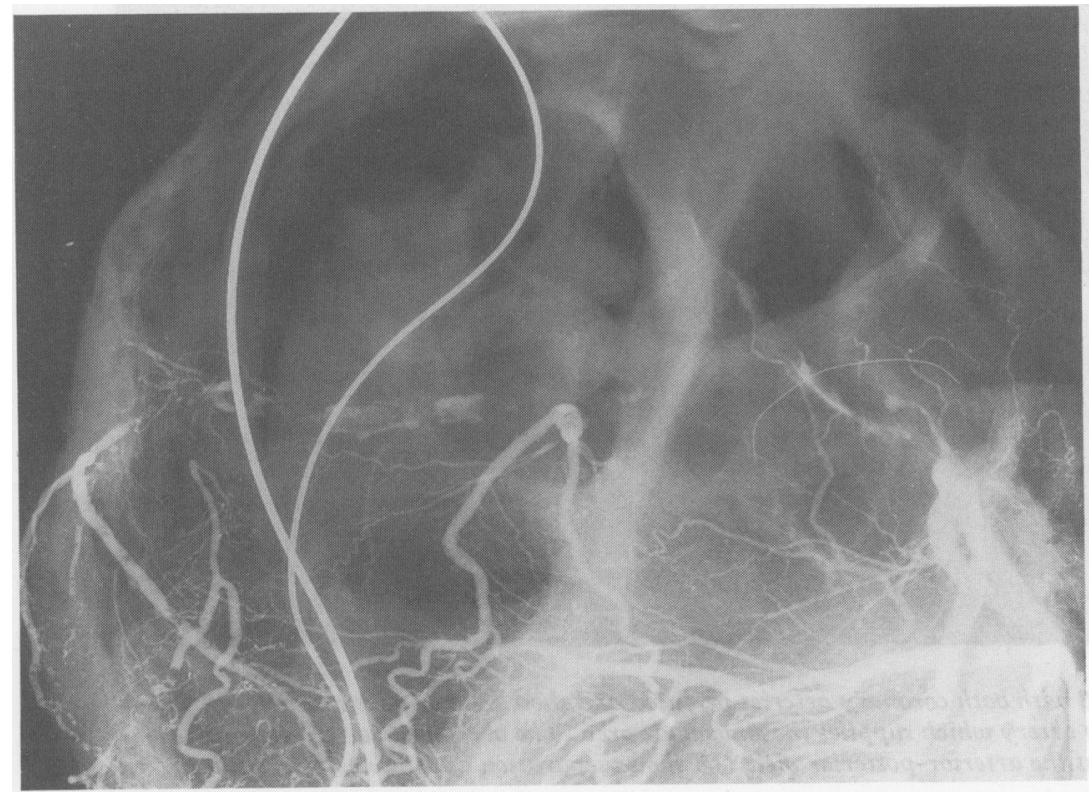

Fig 3 Anterior-posterior angiogram of case 187 after perfusion of both coronary arteries The right main coronary immediately distal to the conus artery was completely blocked. There was no filling of the atrial arterial branches on the right side. 

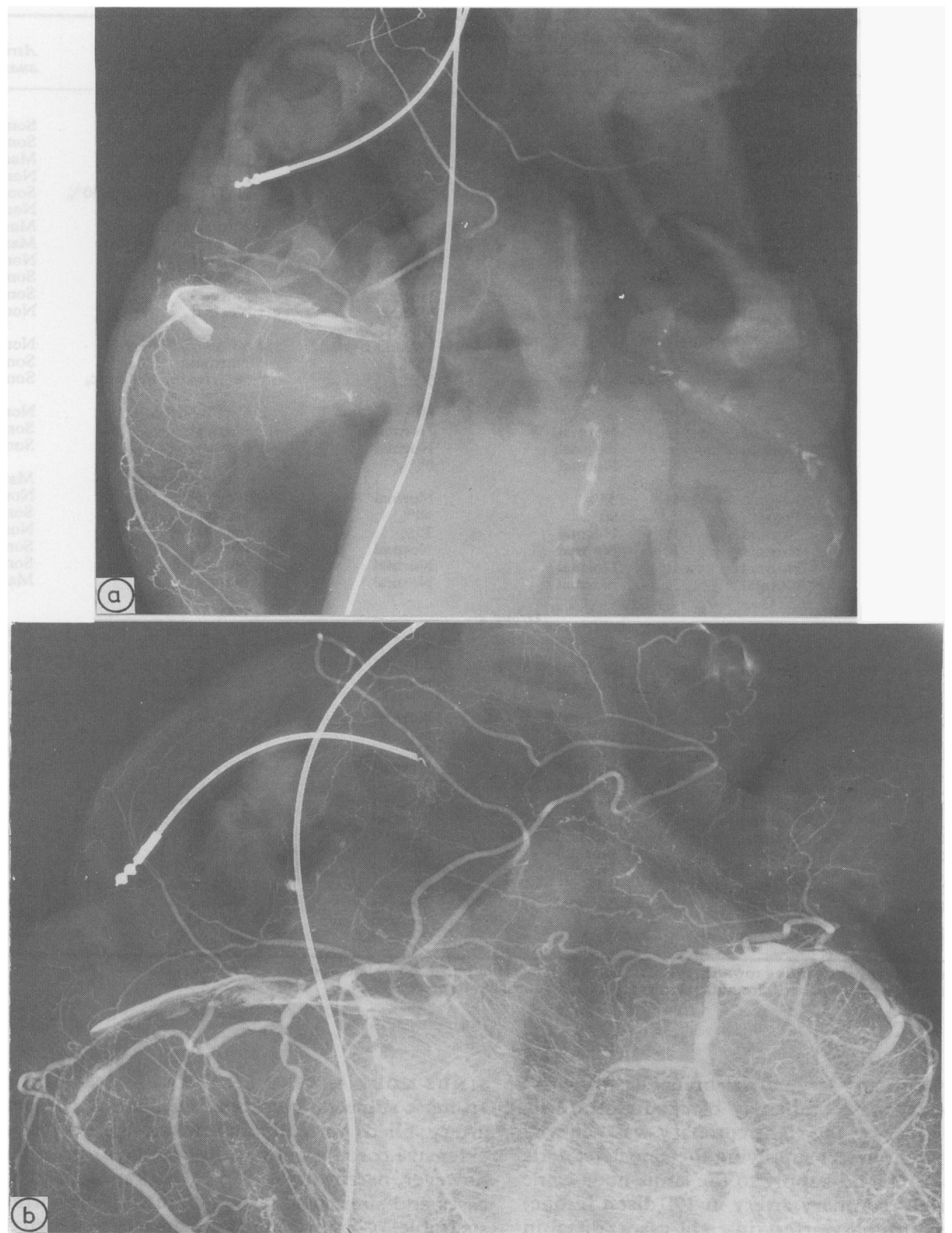

Fig 4 Anterior-posterior angiograms of case 169: (a) perfusion of the right coronary shows that this was almost completely obstructed close to its origin. The sinus node artery filled but to a reduced extent and smaller tributaries cannot be seen; (b) taken after both coronaries had been perfused, showing increased filling of the sinus node artery and adjacent vessels. 
Table 4 Origin of the sinoatrial node artery in groups 1 and 2 compared with that described by James ${ }^{18}$ and Hutchinson ${ }^{19}$

\begin{tabular}{|c|c|c|c|c|c|c|c|c|}
\hline \multirow[b]{2}{*}{ Artery } & \multicolumn{2}{|c|}{ Group 1} & \multicolumn{2}{|c|}{ Group 2} & \multicolumn{2}{|c|}{ James } & \multicolumn{2}{|c|}{ Hutchinson } \\
\hline & No & $\%$ & No & $\%$ & No & $\%$ & No & $\%$ \\
\hline $\begin{array}{l}\text { Right proximal } \\
\text { Right distal }{ }^{\star} \\
\text { Left proximal } \\
\text { Left distal }{ }^{\star} \\
\text { Total }\end{array}$ & $\begin{array}{r}16 \\
1 \\
5 \\
3 \\
25\end{array}$ & $\begin{array}{r}64 \\
4 \\
20 \\
12\end{array}$ & $\begin{array}{r}32 \\
3 \\
18 \\
1 \\
54\end{array}$ & $\begin{array}{r}59 \\
6 \\
33 \\
2\end{array}$ & $\begin{array}{r}55 \\
2 \\
43 \\
2 \\
106 \dagger\end{array}$ & $\begin{array}{r}52 \\
2 \\
41 \\
2\end{array}$ & $\begin{array}{r}19 \\
7 \\
11 \\
3 \\
40\end{array}$ & $\begin{array}{r}48 \\
18 \\
28 \\
8\end{array}$ \\
\hline
\end{tabular}

*The second (intermediate) and third (posterior) parts of the artery.

†Including two with dual supply and two with unknown origin.

Case 185 was unusual because the atrial artery supplying the branch to the sinus node was blocked at a point approximately two thirds along its course.

The sinus node artery filled normally in all of the 54 subjects in group 2 . There was a major obstruction of the parent vessel in three, however, and in cases 162 and 146 the right main coronary artery was completely blocked and the sinus node artery filled via extensive anastomotic networks coming from the left coronary. In case 86 the sinus node artery was a branch of the left coronary, which was $80 \%$ narrowed; initial injection of the right coronary artery produced some filling by anastomotic channels and filling through the left coronary was normal.

\section{CONTRALATERAL CORONARY ARTERY}

In seven cases in group 1 the contralateral artery or one of its major branches was obstructed by $\geqslant 50 \%$. Two of these (216 and 144) had no apparent anastomotic vessels, but in the other five the findings were compatible with a steal phenomenon because there were some or many anastomotic vessels associated with major obstruction of the contralateral coronary artery.

In group 2 there was $\geqslant 50 \%$ obstruction of the contralateral artery or its main branches in nine, including two of those with major disease of the other coronary artery. None of the remaining seven cases had many anastomotic vessels: five had some and two had none.

In the four patients dying soon after acute myocardial infarction postmortem angiography showed that the parent vessel to the sinus node artery was completely blocked in two and that there was severe bilateral coronary disease in the other two cases, one of which also fulfilled the criteria for a potential steal phenomenon.

\section{Discussion}

The anatomy of the blood supply to the atria and sinus node is very variable ${ }^{14-16}$ and if sinus node dysfunction were usually the result of ischaemia it might be expected that certain anatomical patterns would be unduly common in this condition because they predisposed the area to ischaemia. ${ }^{17}$ Conversely other vascular configurations might reduce the risk of hypoxia because they give considerable scope for anastomosis between the different arterial branches to the atrium. ${ }^{18} 19$ Nerantzis and Avgoustakis suggest that the so-called $S$ shaped sinus node artery arising from the distal part of the left circumflex may be particularly beneficial in cases of atherosclerosis, since it can function as a bridge between the two major coronary trunks. ${ }^{20}$ This makes the sinus node area in a heart "much less vulnerable to atherosclerotic disease than would be the case otherwise". In practice, the basic coronary anatomy of the subjects of the present study was generally similar in groups 1 and 2 and findings in both groups resembled those in other series of subjects without sinus node disease (table 4).

It is unwise to make dogmatic deductions from necropsy angiograms about the likely state of the circulation in life, because the static filling pressure applied to dead vessels must be very different from the pulsatile flow occurring in the live circulation. The steady pressure of $130 \mathrm{~mm} \mathrm{Hg}$ that was used would tend to fill peripheral vessels even if a major obstruction was present, yet under such circumstances in life tissue ischaemia might be expected, particularly when under increased load. Also the degree of coronary spasm cannot be assessed and there is evidence that spasm is often present in atheromatous heart disease. The influence of extracardiac anastomotic vessels ${ }^{21}$ could not be assessed in this study and even intercoronary anastomoses may have been difficult to identify. Radiographs taken in a single plane may be misleading since vessels appear to criss-cross each other and the scope for anastomosis may seem very great. Further views, however, will disclose the true arrangement and with three projections it is usually possible to confirm the presence of collateral channels. In some instances we studied up to six views after each injection but the additional plates did not materially add to the information. When collaterals are found it may be difficult to assess their importance because 
606

they vary considerably in size, length, and morphology.

In most patients with chronic sinoatrial disorder in the present study the blood supply to the sinus node was not obstructed by disease of the large arteries. Significant arterial lesions were relatively common, however; and these caused reduced filling of the sinoatrial node artery in five of 25 cases and the potential for a steal phenomenon in a further five cases. There is some uncertainty about the effects of the lesions in two of these cases (215 and 150) where the principal contralateral arterial lesions were in the anterior descending branch of the left coronary artery, a vessel which contributes less to the atrial anastomotic system than do the circumflex and right coronary arteries. All of the cases in group 2 showed satisfactory filling of the sinus node artery, although in three collateral vessels from the contralateral coronary artery made a major contribution. The angiographic appearance suggested a potential for a steal phenomenon in five cases, but in three the predominant obstruction was in the left anterior descending artery. There had been no evidence of sinus node dysfunction during life in any of these cases. The findings in the four cases of acute sinus node dysfunction after cardiac infarction suggest that, had they survived, at least three would have been left with ischaemia of the sinus node. Improved methods of treatment may increase the number of patients with impaired sinoatrial function who survive the acute episode.

We thank Professor Michael Davies of St George's Hospital for his help and Professor Peter Anthony for his cooperation throughout this study. We are indebted to the clinicians of Devon for their early notification of fatal cases upon which this study relied. This work was financed by grants from the Department of Health and Social Security, the British Heart Foundation, and the Northcott Devon Medical Foundation.

\section{References}

1 Fluck DC, Olsen E, Pentecost BL, et al. Natural history and clinical significance of arrhythmias after acute cardiac infarction. Br Heart $J$ 1967;29:170-89.

2 Conde CA, Leppo J, Lipski J, et al. Effectiveness of pacemaker treatment in the bradycardia-tachycardia
Shaw, Linker, Heaver, Evans

syndrome. Am J Cardiol 1973;32:209-14.

3 Hartel G, Tarvensaari T. Treatment of sinoatrial syndrome with permanent cardiac pacing in 90 patients. Acta Med Scand 1975;198:341-7.

4 Scarpa WJ. The sick sinus syndrome. Am Heart $J$ 1976;92:648-60.

5 Parameswaran R, Ohe T, Goldberg $H$. Sinus node dysfunction in acute myocardial infarction. Br Heart $J$ 1976;38:93-6.

6 Hatle T, Bathen J, Rokseth R. Sinoatrial disease in acute myocardial infarction. Long-term prognosis. Br Heart J 1976;38:410-4.

7 Davies MJ, Anderson RH, Becker AE. The conduction system of the heart. London: Butterworth, 1983.

8 Evans R, Shaw DB. Pathological studies in sinoatrial disorder (sick sinus syndrome). Br Heart $J$ 1977;39:778-86.

9 Thery C, Gosselin B, Lekieffre J, Warembourg H. Pathology of sinoatrial node. Correlation with electrocardiographic findings in 111 patients. Am Heart $J$ 1977;93:735-40.

10 Becker AE. General comments. In: Bonke FIM, ed. The sinus node, structure, function and clinical relevance. The Hague: Martins Nijhoff Medical Division, 1978.

11 Shaw DB, Kekwick CA. Potential candidates for pacemakers. Br Heart J 1978;40:99-105.

12 Davies MJ. A histological study of the conduction system in complete heart block. $J$ Pathol Bacteriol 1967;94:351-8.

13 Boucek RJ, Morales AR, Romanelli R, Judkins MP. Coronary artery disease. Pathologic and clinical assessment. Baltimore: Williams and Wilkins, 1984.

14 Spalteholz W. Die Arterien der Herzwand, Anatomische Untersuchungen en Menschen-und Tierherzen. Leipzig: S Hirzel, 1924.

15 Campbell JS. Stereoscopic radiography of the coronary system. Q J Med 1929;22:247-67.

16 James TN, Burch GE. The atrial coronary arteries in man. Circulation 1958;17:90-8.

17 Gazetopoulos N, Ioannidis PJ, Marselos A, et al. Length of main left coronary artery in relation to atherosclerosis of its branches: a coronary arteriographic study. Br Heart $J$ 1976;38:180-5.

18 James TN. Anatomy of the coronary arteries. New York: Paul B Hoeber, 1961.

19 Hutchinson MCE. A study of the atrial arteries in man. J Anat 1978;125:39-54.

20 Nerantzis C, Avgoustakis D. A S-shaped atrial artery supplying the sinus node artery. An anatomical study. Chest 1973;2:274-8.

21 Petelenz T. Extra-coronary blood supply of the sinoatrial node. Cardiologia 1965;47:57-67. 
Appendix Basic data in group 1

\begin{tabular}{|c|c|c|c|c|c|c|}
\hline Case No & Age at death & Sex & $\begin{array}{l}\text { Follow } \\
\text { up (mth) }\end{array}$ & Symptoms and signs & Paced/unpaced & Cause of death \\
\hline $\begin{array}{r}243 \\
214 \\
215 \\
187 \\
150 \\
36 \\
186 \\
169 \\
118 \\
82 \\
226 \\
4 \\
35 \\
101 \\
210 \\
216 \\
39 \\
209 \\
88 \\
185 \\
207 \\
144 \\
184 \\
135 \\
75\end{array}$ & $\begin{array}{l}92 \\
80 \\
69 \\
79 \\
85 \\
64 \\
82 \\
63 \\
56 \\
60 \\
77 \\
65 \\
69 \\
87 \\
70 \\
70 \\
88 \\
77 \\
76 \\
85 \\
78 \\
82 \\
65 \\
76 \\
83\end{array}$ & $\begin{array}{l}M \\
\mathbf{F} \\
\mathbf{F} \\
\mathbf{M} \\
\mathbf{M} \\
\mathbf{F} \\
\mathbf{M} \\
\mathbf{M} \\
\mathbf{M} \\
\mathbf{F} \\
\mathbf{M} \\
\mathbf{F} \\
\mathbf{M} \\
\mathbf{M} \\
\mathbf{M} \\
\mathbf{M} \\
\mathbf{M} \\
\mathbf{M} \\
\mathbf{M} \\
\mathbf{M} \\
\mathbf{M} \\
\mathbf{M} \\
\mathbf{M} \\
\mathbf{M} \\
\mathbf{M}\end{array}$ & $\begin{array}{r}186 \\
155 \\
144 \\
121 \\
97 \\
89 \\
79 \\
78 \\
71 \\
57 \\
49 \\
58 \\
58 \\
30 \\
29 \\
14 \\
12 \\
9 \\
8 \\
7 \\
5 \\
4 \\
2 \\
1 \\
1\end{array}$ & $\begin{array}{l}\text { Syncope, dyspnoea } \\
\text { Syncope, dyspnoea } \\
\text { Syncope, dyspnoea } \\
\text { Dizziness, dyspnoea, chest pain } \\
\text { Syncope, dyspnoea } \\
\text { Syncope, dyspnoea, chest pain } \\
\text { Syncope, dyspnoea } \\
\text { Cardiac failure, chest pain } \\
\text { Dizziness, dyspnoea } \\
\text { Syncope, dyspnoea } \\
\text { Syncope } \\
\text { Syncope, dyspnoea, cardiac failure } \\
\text { Dyspnoea, chest pain } \\
\text { Syncope } \\
\text { Syncope, dyspnoea } \\
\text { Dizziness } \\
\text { Dizziness } \\
\text { Syncope } \\
\text { Syncope, cardiac failure } \\
\text { Syncope } \\
\text { Syncope, cardiac failure } \\
\text { Dizziness, dyspnoea, chest pain } \\
\text { Syncope, dyspnoea } \\
\text { Syncope, cardiac failure } \\
\text { Syncope }\end{array}$ & $\begin{array}{l}\text { Paced } \\
\text { Paced } \\
\text { Paced } \\
\text { Paced } \\
\text { Paced } \\
\text { Paced } \\
\text { Paced } \\
\text { Paced } \\
\text { Paced } \\
\text { Paced } \\
\text { Paced } \\
\text { Paced } \\
\text { Unpaced } \\
\text { Unpaced } \\
\text { Paced } \\
\text { Paced } \\
\text { Unpaced } \\
\text { Paced } \\
\text { Unpaced } \\
\text { Unpaced } \\
\text { Paced } \\
\text { Unpaced } \\
\text { Paced } \\
\text { Paced } \\
\text { Paced }\end{array}$ & $\begin{array}{l}\text { Cerebrovascular accident } \\
\text { Cerebrovascular accident } \\
\text { Myocardial infarction } \\
\text { Carcinoma/bronchus } \\
\text { Cerebrovascular accident } \\
\text { Left ventricular failure } \\
\text { Bronchopneumonia } \\
\text { Myocardial infarction } \\
\text { Unknown } \\
\text { Cerebrovascular accident } \\
\text { Carcinomatosis } \\
\text { Pacemaker failure } \\
\text { Myocardial infarction } \\
\text { Bronchopneumonia } \\
\text { Cardiac failure } \\
\text { Carcinoma/oesophagus } \\
\text { Bronchopneumonia } \\
\text { Cerebrovascular accident } \\
\text { Cardiac failure } \\
\text { Unknown } \\
\text { Renal failure } \\
\text { Unknown but sudden } \\
\text { Cardiac failure } \\
\text { Unknown } \\
\text { Cardiac failure }\end{array}$ \\
\hline
\end{tabular}

